\section{Thermal Systems Process and Components Laboratory}

The focus of the Thermal Systems Process and Components Laboratory at NREL's Energy Systems Integration Facility (ESIF) is to research, develop, test, and evaluate new techniques for thermal energy storage systems that are relevant to utility-scale concentrating solar power plants. The laboratory holds test systems that can provide heat transfer fluids for the evaluation of heat exchangers and thermal energy storage devices. The existing system provides molten salt at temperatures up to $800^{\circ} \mathrm{C}$. This unit is charged with nitrate salt rated to $600^{\circ} \mathrm{C}$, but is capable of handling other heat transfer fluid compositions. Three additional test bays are available for future deployment of alternative heat transfer fluids such as hot air, carbon dioxide, or steam systems.

\section{Laboratory Specifications}

The 950 sq. ft. laboratory features four test bays, each capable of supporting a $30 \mathrm{~kW}$ test system. One bay resides inside in a HEPA-rated enclosure so articles containing nanofluids can be tested. Outside cooling air is available from a roofmounted blower and hot air can be exhausted through the ceiling.

The laboratory contains $30 \mathrm{~kW}$ test systems designed to provide hot heat transfer fluid to pilot-scale thermal energy storage systems. Storage systems can be cycled through multiple charge and discharge cycles to evaluate performance and storage efficiency.

\section{Application Scenarios}

The Thermal Systems Process and Components Laboratory performs pilot-scale thermal energy storage system testing through multiple charge and discharge cycles to evaluate heat exchanger performance and storage efficiency. The laboratory equipment can also be utilized to test instrument and sensor compatibility with hot heat transfer fluids.

Future applications in the laboratory may include the evaluation of thermal energy storage systems designed to operate with supercritical heat transfer fluids such as steam or carbon dioxide. These tests will require the installation of test systems capable of providing supercritical fluids at temperatures up to $700^{\circ} \mathrm{C}$.

\section{Partner with Us}

Work with NREL experts and take advantage of the state-of-the-art capabilities at the ESIF to make progress on your projects, which may range from fundamental research to applications engineering. Partners at the ESIF's Thermal Systems Process and Components Laboratory may include:

- CSP technology developers

- Utilities

- Certification laboratories

- Government agencies

- Universities

- Other National laboratories

\section{Contact Us}

If you are interested in working with NREL's Thermal Systems Process and Components Laboratory, please contact:

\section{ESIF Manager}

Carolyn Elam

Carolyn.Elam@nrel.gov

303-275-4311
Major Laboratory

Equipment

- Four $10 \mathrm{ft} . \times 10 \mathrm{ft}$. test bays for evaluation of $30 \mathrm{~kW}$ thermal systems

- Custom test system to provide hot salt or molten metal heat transfer fluid to the test device

- LabView computer interface for unit control and data acquisition

- Thermal energy storage process test loops

- Outdoor air feed and exhaust for system cooling

- HEPA-rated enclosure for testing systems containing nanomaterials

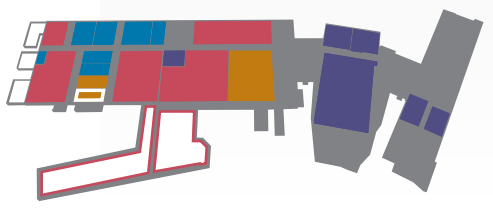

National Renewable Energy Laboratory 15013 Denver West Parkway, Golden, CO 80401 303-275-3000 • www.nrel.gov
NREL is a national laboratory of the U.S. Department of Energy

Office of Energy Efficiency and Renewable Energy

Operated by the Alliance for Sustainable Energy, LLC

NREL/FS-5500-52846 • October 2011

Printed with a renewable-source ink on paper containing at least $50 \%$ wastepaper, including $10 \%$ post consumer waste. 